\title{
REORIENTASI HUKUM PEMILUKADA YANG MENSEJAHTERAKAN RAKYATNYA
}

\author{
Retno Saraswati \\ Fakultas Hukum Universitas Diponegoro Semarang \\ E-mail: saraswatiretno@yahoo.co.id
}

\begin{abstract}
Currently, the implementation of direct election for regional leader (pilkada) is not able to create people's welfare. Even it tends to harm the morale of state officials and people as well. In regard to this, the state should take immediate political measures to change direct local elections law into indirect one. In the perspective of a democratic state, indirect local election is in line with the concept of Indonesian democracy and also in accordance with legal politics for people's welfare. Thus, the election law is more meaningful to the Indonesian society.
\end{abstract}

Keywords : Welfare, Indirect local elections, legal policy

\begin{abstract}
Abstrak
Potret pemilukada saat ini menunjukkan bahwa pelaksanaan pemilukada tidak mampu menciptakan kesejahteraan rakyat, bahkan menyebabkan semakin rusaknya moral para pejabat dan rakyatnya. Menyikapi hal tersebut negara harus segera mengambil sikap untuk segera merubah politik hukum pemilukada langsung menjadi pemilukada tidak langsung. Dalam perspektif negara demokrasi, pemilukada tidak langsung sejalan dengan konsep demokrasi yang ada di Indonesia, dan sesuai dengan politik hukum untuk mensejahterakan rakyat, agar hukum pemilukada lebih bermakna bagi rakyat Indonesia.
\end{abstract}

Kata kunci: kesejahteraan, pemilihan kepala daerah tidak langsung, politik hukum

\section{Pendahuluan}

Suatu negara didirikan tentunya memiliki tujuan tertentu, demikian juga negara Indonesia didirikan dengan tujuan sebagaimana tercantum dalam Alinea keempat Pembukaan Undang-Undang Dasar Negara Republik Indonesia Tahun 1945. ${ }^{1}$ Oleh karena itu tujuan mensejahterakan rakyat dapat dikatakan sebagai politik hukum secara ideal yang menjadi pemandu dalam membentuk hukum, termasuk hukum pemilukada di Indonesiapun juga harus bermuara pada kesejahteraan masyarakat. ${ }^{2}$

\footnotetext{
Tujuan Negara Republik Indonesia sebagaimana disebutkan dalam Alinea Keempat Pembukaan UUDNRI 1945 adalah melindungi segenap bangsa Indonesia dan seluruh tumpah darah Indonesia, memajukan kesejahteraan umum, mencerdaskan kehidupan bangsa dan ikut melaksanakan ketertiban dunia yang berdasarkan kemerdekaan, perdamaian abadi dan keadilan sosial

2 Hukum tentang pemilihan umum merupakan bagian dari hukum nasional, dan dalam membangun hukum nasional tersebut adalah dalam rangka untuk mencapai tujuan negara yakni mensejahterakan rakyat. Lihat Frankiano B. Randang, "Membangun Hukum Nasional yang De-
}

Secara yuridis, landasan pelaksanaan pemilihan umum kepala daerah (Pemilukada) adalah Pasal 18 ayat (4) Undang-Undang Dasar Negara Republik Indonesia Tahun 1945, yang menentukan bahwa Gubernur, Bupati, dan Walikota masing-masing sebagai kepala pemerintah daerah provinsi, kabupaten, dan kota dipilih secara demokratis. Dipilih secara demokratis disini bermakna bahwa pemilihan kepala daerah dapat dilaksanakan secara tidak langsung maupun secara langsung oleh rakyat. Ketentuan ini lebih lanjut diturunkan dalam bentuk undang-undang sebagaimana diatur dalam UU No. 32 tahun 2004 Tentang Pemerintahan Daerah, sangat jelas sekali bahwa undang-undang telah menetapkan bahwa pemilihan kepala daerah dilaksanakan secara langsung oleh rakyat, sehingga sejak tahun 2005 dimulailah pemilihan kepa-

mokratis dan Cerdas Hukum", Jurnal Ilmiah Hukum Servanda, Vol. 3 No. 5 Januari 2009, Manado: FH UNSRAT, hlm 1-2 
la daerah itu secara langsung oleh rakyat di Indonesia.

Sistem pemilihan kepala daerah secara langsung dalam perspektif negara demokrasi ${ }^{3}$, merupakan perwujudan dari pelaksanaan demokrasi itu sendiri. Abraham Lincoln ${ }^{4}$ mengatakan bahwa demokrasi adalah pemerintahan yang berasal dari rakyat, oleh rakyat, dan untuk rakyat. Dengan pemilihan kepala daerah secara langsung, maka disitulah esensi kekuasaan rakyat dalam menentukan pemimpinnya melalui pemilu, rakyat sendiri yang akan menentukan dan memilih siapa yang akan menjadi pemimpinnya sesuai dengan pilihannya.

Penguatan pelaksanaan demokrasi di Indonesia tentunya juga harus diimbangi dengan penguatan pada pencapaian tujuan negara yakni kesejahteraan masyarakat. Kuatnya dukungan pemilukada langsung ternyata juga sebanding dengan kuatnya resistensi pemilukada langsung yang tidak mendukung tercapainya tujuan mensejahterakan masyarakat. Jika demikian, mana yang harus diutamakan antara pemilukada langsung atau pencapaian kesejahteraan rakyat, inilah problem yang harus segera ditangani demi penyelamatan negara demi tercapainya tujuan negara. Terkait dengan problematika tersebut, penulis mengkaji tentang hubungan antara hukum pemilukada dengan kesejahteraan rakyat.

\section{Pemilukada dalam Kerangka Teoretis}

Pemilihan kepala daerah secara langsung yang diterapkan di Indonesia tentunya harus dikaji dalam kerangka teoretis yang lebih komprehensif, artinya selain pengkajiannya mendasarkan pada konsep demokrasi, juga dalam perspektif konsep politik hukum nasional Indonesia. Suatu negara disebut negara demokrasi

\footnotetext{
Indonesia menganut paham kedaulatan rakyat atau demokrasi yang dapat kita temukan dasar yuridisnya dalam Pasal 1 ayat (2) Undang-Undang Dasar Negara Republik Indonesia Tahun 1945

4 Mery Yanti, “Menakar Perkembangan Demokrasi Di Aras Lokal”, Jurnal Administratio, Vol. 3 No. 6 Tahun 2009, Lampung:Jurusan Administrasi Negara FISIP UNILA, hlm. 578; Lihat juga Jamhur Poti, “Demokratisasi Media Massa dalam Prinsip Kebebasan", Jurnal Ilmu Politik dan Ilmu Pemerintahan, Vol. 1 No.1 Tahun 2011, Kepulauan Riau: Fakultas IImu Sosial dan IImu Politik UMRAH, hlm. 17
}

jika pemerintahannya dijalankan dengan mendasarkan pada filosofi bahwa pemerintahan itu berasal dari rakyat, oleh rakyat, dan untuk rakyat sebagaimana dikemukakan oleh Abraham Lincoln ${ }^{5}$. Secara garis besar gagasan demokrasi secara konseptual sebenarnya berakar pada konsep mengenai kebebasan, Aidul Fitriciada Azhari $^{6}$ mengklasifikasikan konsep kebebasan menjadi dua yakni konsep kebebasan negatif dan kebebasan positif. Kebebasan negatif dideskripsikan sebagai "bebas dari" (freedom from) yang mengimplikasikan peran negara yang minimal, terutama pada perlindungan keamanan serta kebebasan sipil dan politik warga negara, konsep ini kemudian melahirkan model demokrasi konstitusional. Sementara konsep kebebasan positif dirumuskan sebagai "bebas untuk" (freedom to), dalam pandangan ini kebebasan mengandung konsekuensi adanya jaminan dari negara agar terdapat persamaan kebebasan yang efektif dari semua warga negara untuk menggunakan dan mengembangkan kapasitas dirinya. Konsep kebebasan ini melahirkan model demokrasi partisipatoris yang memandang demokrasi bukan hanya sebagai prosedur legal dan perwakilan belaka, tetapi lebih dari itu memiliki tujuan moral untuk membantu pengembangan kehidupan sosial ekonomi masyarakat sehingga melahirkan keseimbangan antara kebebasan politik dan keadilan sosial. Dengan demikian hukum pemilukada dalam konteks kebebasan positif, juga harus melahirkan keseimbangan kebebasan politik dan membantu pengembangan kehidupan sosial ekonomi masyarakat.

Pemilihan kepala daerah secara langsung oleh rakyat juga perlu dikaji dalam perspektif politik hukum nasional Indonesia. Politik hu$\mathrm{kum}^{7}$ adalah arahan atau garis resmi yang dijadikan dasar pijak dan cara untuk membuat dan melaksanakan hukum dalam rangka mencapai tujuan bangsa dan negara. Dalam arti yang se-

\section{Ibid}

Aidul Fitriciada Azhari, 2005, Menemukan Demokrasi, Surakarta: Universitas Muhammadiyah Surakarta, hlm. 132

7 Fernandes Edy Syahputra Silaban, “Kebijakan Hukum Pidana Terhadap Pengaturan Tindak Pidana Narkotika Di Indonesia”, Jurnal Mahupi, Vol. 1 No.1 Tahun 2013, Medan: Fakultas Hukum USU hlm. 10 
perti itu politik hukum harus berpijak pada tujuan negara yang terkandung di dalam pembukaan UUDNRI Tahun 1945. Politik hukum untuk mencapai tujuan negara bermakna bahwa tujuan negara atau masyarakat Indonesia yang diidamkan sebagai orientasi politik hukum, termasuk penggalian nilai-nilai dasar tujuan negara sebagai pemandu politik hukum. Politik hukum pemilihan kepala daerah saat ini apakah juga untuk mencapai tujuan negara, manakala belum sesuai dengan maknanya, maka perlu juga dilakukan reorientasi.

\section{Potret Pemilihan Kepala Daerah Secara Lang- sung di Indonesia}

Politik hukum sistem pemilihan kepala daerah di indonesia dapat disimpulkan dengan jelas bahwa pemilihan kepala daerah dilakukan secara langsung oleh rakyat, walaupun dalam Pasal 56 ayat (1) UU No. 32 tahun 2004 hanya menentukan bahwa Kepala daerah dan wakil kepala daerah dipilih dalam satu pasangan calon yang dilaksanakan secara demokratis berdasarkan asas langsung, umum, bebas, rahasia, jujur, dan adil, Namun dalam pasal-pasal ${ }^{8}$ selanjutnya dapat kita simpulkan bahwa pemilihan kepala daerah dan wakil kepala daerah dilakukan secara langsung oleh rakyat. Rupanya doro-ngan untuk dilakukan pemilihan kepala daerah dan wakil kepala daerah secara langsung adalah demi meningkatkan otonomi politik dan mendemokratisasikan pemerintahan lokal. ${ }^{9}$ Asumsi umum mengatakan bahwa demokrasi di tingkat lokal akan mendapatkan kekuatan apabila terjadi penyerahan mandat (politik) langsung dari warga kepada para kepala daerah.

Ada beberapa keuntungan ketika pemilukada langsung dilaksanakan. Pertama, terwujudnya legitimasi politik pimpinan daerah, hal

8 Pasal-pasal itu adalah dari Pasal 57 sampai dengan $\mathrm{Pa}$ sal 119 UU No. 32 Tahun 2004, yang mengatur mengenai lembaga penyelenggara, tahapan dalam pemilihan kepala daerah dan wakil kepala daerah, tata cara pemilihan, dan lain sebagainya.

9 Notroda GB. Mandika, "Dampak Pemilihan Kepala Daerah pada Proses Demokratisasi”, Jurnal Ilmu Pemerintahan, Edisi 26 Tahun 2008, Jakarta: Masyarakat IImu Pemerintahan Indonesia, hlm. 25 ini dimungkinkan karena kepala daerah yang dipilih mendapat mandat dan legitimasi yang sangat kuat karena didukung langsung oleh suara pemilih yang nyata (real voters) yang merefleksikan kepentingan konstituen pemilih. Kedua, membangun serta mewujudkan local accountability, ${ }^{10}$ mereka yang terpilih akan meningkatkan kualitas akuntabilitasnya demi pertanggungjawabannya kepada rakyat dan keuntungan dimasa pemilihan yang akan datang. Ketiga, meningkatkan kesadaran politik masyarakat terutama yang berkait dengan kualitas partisipasi publik. ${ }^{11}$

Melihat keuntungan yang demikian, tentunya dengan pimpinan yang dipilih oleh rakyat sendiri diharapkan akan membawa rakyat pada keadaan yang tidak hanya diakui keberadaannya karena mereka dapat menentukan sendiri pilihannya, tetapi juga dapat membawa pada kesejahteraan mereka. Ternyata pemilukada yang saat ini diterapkan tidak dengan serta merta menciptakan keadaan yang demokratik di tingkat lokal dan kesejahteraan rakyat. Hal ini dapat dilihat dari beberapa dampak negatif adanya pemilukada pada saat ini.

Pertama, biaya pemilukada yang sangat tinggi. Pemilukada terlalu makan biaya yang sangat besar ${ }^{12}$ karena paling tidak banyak anggaran daerah (APBD) yang akan dikonsentrasikan pada proses pemilihan kepala daerah. Apalagi kalau harus dilakukan pemilukada ulang, maka jelas anggaran daerah yang akan dikonsentrasikan ke pemilukada semakin besar. Dana pemilukada kabupaten/kota dan provinsi mencapai Rp 15 triliun setahun, dalam 5 (lima) tahun, sekitar Rp 75 triliun habis untuk menyelenggarakan sekitar 300 pesta rakyat di penjuru negeri.

Pemilihan kepala daerah secara langsung akan memakan biaya yang sangat besar, bila

10 J. Kristiadi, "Beberapa Catatan Tentang Politik Lokal dan Pemilihan Kepala Daerah Langsung", Jurnal IImu Pemerintahan, Edisi 26 Tahun 2008, Jakarta: Masyarakat Ilmu Pemerintahan Indonesia, hlm. 56

11 Notroda GB. Mandika, op.cit, hlm. 36

12 Donni Edwin, "Pemilukada dan Perilkaku Korupsi Kepala Daerah", Jurnal Komunitas, Vol 6 No 2 Desember 2012, Semarang: FIS UNNES, hlm. 157 
dibandingkan dengan pemilihan kepala daerah tidak langsung. Logikanya ialah dalam pemilukada tidak langsung hanya dilakukan oleh DPRD semata, sedangkan pemilukada langsung dilakukan dengan mengikutsertakan partisipasi publik, sehingga terjadi perbedaan kebutuhan anggaran diantara keduanya, mulai dari sosialisasi pemilihan itu sendiri, pemilihan panitia pengawas yang baru, pembuatan surat suara, hingga biaya operasional bagi panitia pemilukada langsung. Seandainya alokasi untuk pemilukada langsung itu dialokasikan untuk program-program kesejahteraan masyarakat alangkah bermanfaatnya.

Kedua, Pemilukada sebagai katup korupsi di level lokal maupun nasional. Pemilukada langsung selain menggunakan biaya yang sangat besar yang harus dialokasikan melalui APBD, akan tetapi dari calonnya sendiri itupun membutuhkan biaya yang sangat besar. Biaya yang dikeluarkan oleh calon kepala daerah untuk pemilukada provinsi bisa mencapai 100 milyar, sedang untuk kabupaten/kota bisa mencapai 50 milyar, bahkan disebutkan harga yang dipatok oleh partai politik antara Rp 1 miliar hingga 2 miliar bagi satu calon bupati yang didaftarkan ke KPUD. ${ }^{13}$ Ketika biaya yang dikeluarkan banyak, maka potensi untuk korupsi juga sangat tinggi, logikanya dengan mengeluarkan uang yang begitu besar tentunya setelah menjadi kepala daerah akan berusaha mengembalikan biaya yang telah dikeluarkan tersebut melalui berbagi cara dari modus-modus korupsi yang ditempuh sampai pada korupsi secara terang-terangan. Bagaimana kepala daerah berpikir untuk kesejahteraan rakyat, kalau harus berpikir return of investment.

Sebagai buktinya bahwa banyak kepala daerah yang tersandung kasus korupsi, hampir 70\% baik di tingkat provinsi, kabupaten, mau pun kota kepala daerah yang terjerat kasus korupsi. ${ }^{14}$ Catatan tersebut di dukung oleh ketera-

13 Fitriah, "Fenomena Politik Uang dalam Pilkada", Jurnal Politika, Vol. 1 April 2012, Semarang: FISIP UNDIP, hlm. 1

14 Bernadette Christina Munthe,18 Desember 2013, Ketua Komisi Hukum: 70 persen Kepala Daerah Korup tersedia di website www.tempo.co/read/news/2013/12/18, diakses tanggal 26 Desember 2013 ngan dari Kementerian Dalam Negeri, pada tahun 2013 ada sekitar 311 kepala daerah yang tersangkut kasus korupsi. Tidak hanya itu saja dengan kasus tertangkapnya Ketua Mahkamah Konstitusi karena dugaan penyuapan kasus sengketa pemilukada, inipun membuktikan bahwa pemilukada menjadi katub korupsi di level pusat.

Ketiga, jual beli jabatan di tingkat lokal. Akibat biaya yang besar yang dibutuhkan dalam pemilukada, maka demi mengembalikan modal yang telah dikeluarkan dan juga untuk mempersiapkan kemenangan pemilukada yang akan datang, selain menggunakan modus-modus korupsi, maka yang terjadi di daerah adalah terjadinya jual beli jabatan. Sebagai contoh untuk menduduki jabatan kepala dinas pendidikan di sebuah kabupaten, calon kepala dinas bersangkutan harus membayar 500 juta rupiah. Kalau demikian, akan terjadi pungutan secara bertingkat, dan anggaran-anggaran yang seharusnya untuk pengembangan pendidikan akhirnya banyak yang hanya bersifat fiktif saja.

Keempat, menurunnya moralitas baik penyelenggara negara maupun rakyat. Pelaksanaan pemilukada langsung secara esensial bertujuan untuk lebih menguatkan legitimasi politik penguasa di daerah. Namun, dalam konteks lain terjadi kontraproduktif dengan upaya pemberantasan korupsi karena pemilukada langsung diindikasikan kuat akan makin menyuburkan budaya "money politics". Kasus money politics yang saat ini terjadi bahkan dilakukan secara sistematis, terstruktur, dan masif. Contoh kasus money politics di Kabupaten Kotawaringin Barat dilakukan secara menyeluruh dan terencana, yang melibatkan KPPS, PPS, PPK dan Ketua RT, baik tersembunyi maupun terang-terangan membagikan uang Rp. 150.000,- hingga Rp. 200.000,- pada setiap warga, bahkan kandidat terpilih juga menjanjikan akan memberikan tanah 2 ha/orang serta melakukan intimidasi terhadap warga masyarakat. ${ }^{15}$ Lain lagi yang terjadi di Kabupaten Mandailing natal, money

15 Veri Junaidi, “Pelanggaran Sistematis, Terstruktur dan Masif: Suatu Sebab Pembatalan Kehendak Rakyat dalam Pemilihan Kepala Daerah Tahun 2010", Jurnal Konstitusi, Vol. 7 No.5 Tahun 2010, Jakarta: Mahkamah Konstitusi, hlm. 61-62 
politics dilakukan dengan membagikan voucher dari tingkat tim kampanye hingga tingkat RW dan RT. ${ }^{16}$

Kendati sulit dibuktikan kenyataannya dalam pemilukada langsung budaya "money politics" semakin subur, hal ini selain dapat merusak para pejabat juga masyarakat pada umumnya. Fakta sebagaimana tersebut di atas menunjukkan moralitas pejabat yang semakin menurun, kurang memikirkan rakyatnya dan lebih berkonsentrasi pada kepentingan pribadi. Masyarakat dengan pendidikan terbatas, masyarakat yang masih lapar, membuat politik uang menjadi pemenang pemilukada. Banyak kalangan masyarakat kalau tidak ada uang tidak akan datang dan memberikan suara pada pemilukada. Inilah dampak terbesar dari "money politics", moral rakyat semakin rusak, berpikir pragmatis, hanya berorientasi pada materi saja.

Kelima, konflik Pemilukada. Konflik yang bersumber dari premanisme politik dan pemaksaan kehendak, gejala ini sudah muncul di beberapa daerah, saat massa pendukung calon memprotes keputusan KPU daerah. Konflik tidak hanya itu saja, konflik pada tahapan-tahapan yang lainpun seringkali muncul. Konflik pemilukada terus menerus, karena banyak yang tidak siap kalah dalam pemilukada. Sejak 2005 tercatat tidak sedikit kerusuhan yang terjadi akibat ketidaksiapan pasangan kandidat menerima kekalahan pemilukada. Kerusuhan itu membawa kerugian bagi masyarakat lokal setempat dengan pembakaran aset pemda dan bahkan menyebabkan warga meninggal dunia. Lihat saja gugatan di Mahkamah Konstitusi, untuk diluar Jawa hampir seluruh pemilukada hasilnya digugat ke Mahkamah Konstitusi, dan ini menjadi beban semakin beratnya tugas dari Mahkamah Konstitusi.

Dari potret pelaksanaan pemilukada pada saat ini terlihat bahwa pelaksanaan pemilukada tidak mampu menciptakan kesejahteraan rakyat, bahkan bahaya yang paling besar adalah

$16 \quad$ Ibid semakin rusaknya moral para penyelenggara negara dan rakyat, sehingga dapat dikatakan antara kemanfaatan dan kemadaratannya lebih banyak kemadaratannya. Bahkan agenda pemilukada yang terlalu sering memunculkan kebosanan di masyarakat, fenomena di beberapa daerah hampir serupa dengan angka golongan putih yang tinggi.

\section{Sistem Pemilihan Kepala Daerah yang Demo- kratis dan Mensejahterakan Rakyat.}

Merujuk pada realitas tersebut di atas, ternyata dalam pelaksanaan pemilukada (hukum pemilukada) seba-gaimana diatur dalam UU No. 32 Tahun 2004 menunjukkan bahwa di satu sisi kehidupan demokrasi di Indonesia semakin meningkat luar biasa karena partisipasi masyarakat semakin menguat, sementara di sisi yang lain pemilihan kepala daerah secara langsung tidak mampu menciptakan kesejahteraan rakyat, maka hal tersebut perlu dikaji ulang agar sistem ini pada akhirnya juga bermuara pada kesejahteraan masyarakat. Apalah artinya demokrasi yang maju kalau rakyatnya semakin sengsara, tentunya ini tidak sesuai dengan tujuan negara yang selama ini dicita-citakan.

Jika mengacu pada apa yang disampaikan Satjipto Rahardjo ${ }^{17}$ tentang negara hukum yang membaha-giakan rakyat dan didukung dengan konsep hukum progresif, maka negara hukum yang membahagiakan rakyatnya juga cenderung untuk menjadi negara hukum yang progresif, bila dilihat dari inisiatif yang selalu datang dari pihak negara. Untuk mewujudkan negara tersebut, maka negara akan selalu aktif mengambil inisiatif untuk bertindak. Pendapat yang juga sangat penting mendasari negara hukum yang membahagiakan rakyatnya adalah pendapat dari Sri Edi Swasono ${ }^{18}$ juga mengemukakan hal yang senada bahwa dia menginginkan campur tangan aktif negara untuk menjaga dan menja-

\footnotetext{
17 Satjipto Rahardjo, 2009, Negara Hukum yang Membahagiakan Rakyatnya, Yogyakarta: Genta Publishing, hlm. 106

$18 \quad$ Ibid, hlm 84
} 
min ekonomi Indonesia benar-benar untuk sebesar-besarnya kemakmuran rakyat.

Sudah saatnya dengan fenomena pelaksanaan hukum pemilukada yang demikian, menuntut segera peran negara untuk segera mengambil tindakan untuk mengevaluasi bahkan merubah hukum pemilukada yang tidak mensejahterakan rakyatnya, bukankah hukum yang diciptakan seharusnya untuk mensejahterakan rakyatnya. Sistem pemilihan kepala daerah sebagaimana diatur dalam UU No. 32 Tahun 2004 inipun janganlah dilihat sebagai bangunan final, melainkan yang secara terus menerus dibangun untuk mencapai tujuan nasional. Sistem pemilihan kepala daerah adalah proses untuk makin menampilkan ciri ke-Indonesiaan di tengah-tengah banyak demokrasi di dunia, masing-masing juga memiliki karakteristik sendiri.

Sebenarnya sistem apapun yang akan dipilih oleh negara dalam penyelenggaraan pemerintahannya tidak ada yang salah maupun tidak ada yang benar, yang tepat adalah yang sesuai dengan kondisi dan situasi negara itu sendiri serta pilihan sistem tersebut harus bermuara pada tujuan negara yang bersangkutan. Demikian juga sistem pemilihan kepala daerah secara langsung yang terjadi di Indonesia antara dampak positif dan negatifnya, lebih banyak dampak negatifnya, oleh karena itu menurut penulis sistem pemilihan kepala daerah baik untuk provinsi, kabupaten, maupun kota dikembalikan pada sistem yang lama yakni pemilihan kepala daerah oleh DPRD atau pemilihan secara tidak langsung.

Sebenarnya wacana ini ${ }^{19}$ juga sudah muncul dalam draf Rancangan Undang-Undang Pemilihan Kepala Daerah yang merupakan revisi UU No. 32 Tahun 2004, ada dua kutub besar di gedung Senayan terbentuk dalam memandang poin penting, gubernur yang tidak dipilih langsung oleh rakyat atau walikota/bupati yang tidak perlu dipilih langsung oleh rakyat. Secara konstitusional, pemilihan kepala daerah di atur dalam Pasal 18 ayat (4) UUDNRI Tahun 1945, di

19 Lihat juga Wendy Melfa, "Menggagas Amandemen UUD 1945 dari Pemilukada", Jurnal Dinamika Hukum, Vol.13 No.1 Tahun 2013, Purwokerto: FH Universitas Jenderal Soedirman, hlm. 172 situ hanya disebutkan bahwa Gubernur, Bupati, dan Walikota masing-masing sebagai kepala pemerintah daerah provnsi, kabupaten, dan kota dipilih secara demokratis. Di sini jelas sekali bahwa pemilihan kepala daerah dipilih secara demokratis, penafsiran secara demokratis bisa dilaksanakan secara langsung maupun secara tidak langsung, sehingga bersifat open legal poli$c y$. Sehingga dengan pemilihan kepala daerah oleh DPRDpun tidak melanggar konstitusi.

Jika dicermati, sebenarnya pengaturan sistem pemilihan kepala daerah secara tidak langsung itupun selain sesuai dengan konstitusi terutama Pasal 18 Ayat (4) UUDNRI Tahun 1945 juga sesuai dengan negara Indonesia yang mengadopsi konsep kedaulatan rakyat (Pasal 1 Ayat (2) UUDNRI Tahun 1945). Pemilihan kepala daerah secara langsung dalam konteks negara demokrasi, merupakan perwujudan dari kekuasaan atau kedaulatan rakyat itu sendiri terutama dalam menentukan pimpinan daerahnya. Sebenarnya pemilihan kepala daerah oleh DPRD itupun bukan berarti rakyat dikebiri kekuasaannya atau kedaulatannya, karena DPRD itupun wakil dari rakyat yang dipilih secara langsung oleh rakyat. Melalui DPRD itulah rakyat mendelegasikan kekuasaannya untuk memilih kepala daerahnya. Bahkan hal ini sesuai dengan dengan politik hukum ideal sebagaimana kita temukan dalam Pembukaan UUDNRI Tahun 1945, yakni kerakyatan yang dipimpin oleh hikmat kebijaksanaan dalam permusyawaratan/perwakilan (Sila Keempat Pancasila). Sebenarnya pemilihan kepala daerah melalui DPRD menunjukkan sistem perwakilan tersebut, karena DPRD adalah wakil rakyat yang dipilih oleh rakyat sendiri secara langsung untuk menyalurkan aspirasi dari rakyatnya. Masalah demokratis bisa terjadi asalkan dalam mekanisme perekrutannya juga secara demokratis, sehingga tidak menjadi masalah kalaupun kepala daerah itu dipilih oleh DPRD.

Mengacu pada konsep kebebasan positif yang dirumuskan sebagai "bebas untuk" (freedom to), dalam pandangan ini kebebasan mengandung konsekuensi adanya jaminan dari negara agar terdapat persamaan kebebasan yang efektif dari semua warga negara untuk meng- 
gunakan dan mengembangkan kapasitas dirinya. Konsep kebebasan ini melahirkan model demokrasi partisi-patoris yang memandang demokrasi bukan hanya sebagai prosedur legal dan perwakilan belaka, tetapi lebih dari itu memiliki tujuan moral untuk membantu pengembangan kehidupan sosial ekonomi masyarakat sehingga melahirkan keseimbangan antara kebebasan politik dan keadilan sosial.

Pemilihan kepala daerah secara langsung merupakan wujud kebebasan politik bagi warga negara, karena dengan pemilihan secara langsung warga negara bebas untuk menentukan calon pemimpinnya sendiri, namun dalam praktiknya berdampak pada masalah kesejahteraan masyarakat. Di sinilah tidak adanya keseimbangan antara kebebasan politik dan kesejahteraan masyarakat. Di sini jelas bahwa demokrasi itupun harus melahirkan keseimbangan antara kebebasan individu dan kesejahteraan masyarakat, sehingga manakala demokrasi yang dipilih belum memunculkan keseimbangan itu, maka perlu dicari demokrasi yang dapat memunculkan keseimbangan tersebut.

Ditinjau dari perspektif demokrasi, maka eksistensi lemah kuatnya struktur hak pribadi dan hak undang-undang tergantung dari kuat lemahnya hak sosial yang melingkupinya. Hak pribadi pada suatu negara yang mengutamakan kepentingan umum (negara sosialis) demikian lemah kedudukannya karena segala sesuatunya harus mengutamakan kepentingan umum. Sebaliknya pada negara yang bersistem liberalisme yang mengutamakan aspek individual, hak sosial akan memiliki kedudukan yang lebih lemah.

Gagasan demokrasi berdasarkan karakter bangsa Indonesia terlihat dalam wacana mengenai kepribadian bangsa Indonesia yang dipandang sebagai dasar konsepsi dari demokrasi Indonesia. Kendatipun tidak dapat dikatakan sebagai konsep tunggal, namun umumnya ada kesepakatan bahwa kepribadian bangsa Indonesia menunjuk pada konsep kekeluargaan atau gotong royong ${ }^{20}$ yang mencerminkan paham kolektivisme. Kehidupan rakyat Indonesia selalu dipenuhi rasa bersama atau kolektivitas, dalam segala urusan rakyat Indonesia selalu menyelesaikan secara bersama-sama dan saling tolong menolong, inilah dasar persekutuan asli di Indonesia yakni kolektivitas. Sehingga tidak ada salahnya kalaupun pemilukada itu diserahkan kepada DPRD, demi tujuan bersama yakni mensejahterakan rakyatnya.

Terkait dengan uraian tersebut di atas dapat dikatakan pula bahwa politik hukum pemilukada yang ada dalam UU No. 32 tahun 2004 ini tidak sesuai dengan politik hukum idealnya yakni politik hukum untuk mencapai tujuan negara (mensejahterakan rakyatnya). Walaupun politik hukum secara instrumental sebagaimana tertuang dalam UU No. 32 Tahun 2004 tersebut sesuai dengan politik hukum secara dasar sebagaimana tertuang dalam UUDNRI Tahun 1945. Dapat dijelaskan disini bahwa politik hukum dapat diklasifikasikan menjadi tiga bagian yakni politik hukum secara ideal yakni yang ada dalam Pembukaan UUDNRI Tahun 1945, politik hukum secara dasar yakni yang ada dalam pasal-pasal UUDNRI Tahun 1945, dan politik hukum secara instrumental yakni yang ada dalam Undang-Undang. Seharusnya antara ketiganya harus konsisten, politik hukum secara ideal akan menjadi pijakan bagi politik hukum secara dasar, dan politik hukum secara dasar menjadi pijakan bagi politik hukum secara instrumental.

Di tambah lagi kondisi tersebut dipicu oleh pelaksanaan otonomi daerah yang belum mampu menciptakan kesejahteraan rakyat. Jika demikian faktanya, mengingat hukum itu dibentuk untuk menciptakan kesejahteraan rak-

20 Konsep gotong royong diungkapkan oleh Hatta pada sidang BPUPKI yang mengatakan: “.... Kita mendirikan negara baru di atas dasar gotong royong dan hasil usaha bersama, demikian juga Soekarno yang mengaitkan konsepsi sosio-demokrasi dengan tradisi bangsa Indonesia yang disebutnya sebagai perkataan Indonesia tulen yakni gotong royong, dengan prinsip ini Soekarno menggambarkan negara Indonesia adalah negara gotong royong yang mengandung arti negara "semua buat semua, satu buat semua, semua buat satu". Lihat Aidil Fitriciada Azhari, 2005, Menemukan Demokrasi, Surakarta: Universitas Muhammadiyah Surakarta, hlm. 99 
yat, maka secara instrumental politik hukumnya harus segera dirubah, karena ini merupakan arah bagi pelaksanaan hukumnya. Politik hukum secara instrumental yang menyatakan politik hukum pemilihan kepala daerah secara langsung harus segera diubah atau diganti menjadi politik hukum pemilihan kepala daerah secara tidak langsung, dengan berubahnya politik hukum tersebut, segera undang-undang yang mengatur pemilihan kepala daerah secara langsung juga akan diganti dengan sistem pemilihan kepala daerah secara tidak langsung atau melalui DPRD.

Berdasarkan perspektif negara hukum, maka secara praksis para penyelenggara negara hendaknya dipandu dan disemangati apakah hukum yang dibentuk sudah mensejahterakan atau membahagiakan rakyatnya. Sejalan dengan pemikiran Satjipto Rahardjo, tentang paradigma "hukum untuk manusia", maka hukum untuk manusia meninggalkan cara berhukum yang hanya didasarkan pada olah pikir atau logika yang linier, dan mengoreksinya dengan cara berhukum yang mengejar makna kemanusiaan dari hukum. ${ }^{21}$

Di sinilah saatnya negara mengambil peran, senada apa yang disampaikan oleh Francis Fukuyama $^{22}$ bahwa suatu negara yang kuat ditandai kemampuannya untuk merancang dan melaksanakan kebijakannya serta menegakkan hukum secara bersih dan transparan, tanpa harus menebarkan ancaman. Elemen dasar yang ada pada negara yang kuat adalah otoritas yang efektif dan terlembaga. Jika terjadi pelanggaran atau penentangan terhadap otoritas ini, ia mampu mengatasinya, kalau perlu dengan alatalat pemaksa yang secara sah dikuasainya. Hanya dengan kekuatan semacam inilah negara mampu menjaga keamanan, ketertiban, kebebasan serta jika bersifat intervensionis, agar mampu mewujudkan kesejahteraan rakyatnya.

21 Feri Amsari, "Satjipto Rahardjo dalam Jagat Ketertiban Hukum Progresif", Jurnal Konstitusi, Vol. 6 No. 2 Tahun 2009, Jakarta: Mahkamah Konstitusi, hlm. 181. Lihat juga Pusat Studi Konstitusi FH Andalas, "Perkembangan Pengujian Perundang-Undangan di Mahkamah Konstitusi", Jurnal Konstitusi, Vol 7 No.6 Tahun 2010, Jakarta: Mahkamah Konstitusi, hlm. 171

22 Satjipto Rahardjo, op.cit, hlm. 78
Jika negara tidak mampu menjaga otoritas semacam ini, ia disebut sebagai negara lemah.

Menurut hemat penulis, untuk permasalahan pemilukada langsung saat ini belum tepat, Indonesia harus menata dahulu masalah otonomi daerahnya agar dapat menciptakan kesejahteraan rakyat, karena format otonomi daerah yang sekarang ini dalam prakteknya belum mampu menciptakan kesejahteraan rakyat. Jika masalah otonomi sudah baik, maka berangsur dapat dipikirkan mengenai penerapan pemilukada secara langsung, agar masyarakat daerah dapat merasakan kesejahteraan dan melaksanakan demokrasi.

Pemilukada melalui DPRD (tidak langsung) jangan dianggap sebagai kemunduran demokrasi, karena partisipasi politik masyarakat tidak hanya sekedar dilihat saat memberikan hak suaranya, namun yang paling utama langkah ini memang pantas untuk diambil untuk pembenahan sistem politik baik di level pemerintahan maupun masyarakat biasa, yang selanjutnya dituangkan dalam hukumnya. Di sisi yang lain, pertimbangan diambil langkah demikian karena kultur politik masyarakat belum siap, di samping itu selama perekonomian masyarakat masih labil, maka sikap politik masyarakat sangat mudah dibeli dengan uang. Memang tidak ada yang menjamin kalau pemilukada diserahkan kepada DPRD, money politics bisa dihentikan, akan tetapi setidaknya pengawasan bisa lebih dipermudah, karena orangnya sedikit sehingga ruang kontrolnya jauh lebih mudah.

\section{Penutup \\ Simpulan}

Sistem pemilihan kepala daerah secara langsung yang ideal memang akan mengeluarkan biaya yang relatif besar dibandingkan dengan pemilukada secara tidak langsung. Dalam keadaan negara yang ekonominya sudah kuat dan rakyatnya sejahtera tidak akan menjadi masalah, namun manakala diterapkan pada negara Indonesia yang masyarakatnya yang belum sejahtera bahkan kesejahteraannya semakin merosot dengan diterapkannya sistem tersebut, lebih-lebih moral bangsa semakin terpuruk, ma- 
ka apalah arti sistem pemilukada langsung itu dalam mencapai tujuan negara. Oleh karena itu disini dibutuhkan peran negara untuk segera mengambil tindakan untuk segera merubah hukum pemilukada agar dapat mengatur pemilukada yang dapat menciptakan kesejahteraan rakyat, yakni dengan merubah pemilukada langsung menjadi tidak langsung atau dipilih melalui DPRD itulah langkah tepat pada saat ini.

\section{Daftar Pustaka}

Amsari, Feri. "Satjipto Rahardjo dalam Jagat Ketertiban Hukum Progresif". Jurnal Konstitusi. Vol. 6 No. 2 2009, Jakarta: Mahkamah Konstitusi;

Azhari, Aidil Fitriciada. 2005. Menemukan Demokrasi. Surakarta: Universitas Muhammadiyah Surakarta;

Edwin, Donni. "Pemilukada dan Perilkaku Korupsi Kepala Daerah". Jurnal Komunitas. Vol. 6 No. 2 Desember 2012, Semarang: FIS UNNES;

Fitriah. "Fenomena Politik Uang dalam Pilkada". Jurnal Politika. Vol. 3 No. 1 April 2012, Semarang: FISIP UNDIP;

Junaidi, Veri. "Pelanggaran Sistematis, Terstruktur dan Masif: Suatu Sebab Pembatalan Kehendak Rakyat dalam Pemilihan Kepala Daerah Tahun 2010". Jurnal Konstitusi., Vol. 7 No.5 Tahun 2010, Jakarta: Mahkamah Konstitusi;

Kristiadi, J. "Beberapa Catatan Tentang Politik Lokal dan Pemilihan Kepala Daerah Langsung". Jurnal Ilmu Pemerintahan. Edisi 26 Tahun 2008. Jakarta: Masyarakat IImu Pemerintahan Indonesia;

Mandika, Notroda GB. "Dampak Pemilihan Kepala Daerah pada Proses Demokratisasi". Jurnal Ilmu Pemerintahan. Edisi 26 Tahun 2008, Jakarta: Masyarakat IImu Pemerintahan Indonesia;

Melfa, Wendy. "Menggagas Amandemen UUD 1945 dari Pemilukada". Jurnal Dinamika Hukum. Vol. 13 No. 1 Januari 2013, Purwokerto: FH Universitas Jenderal Soedirman;

Munthe, Bernadette Christina. 18 Desember 2013. "Ketua Komisi Hukum: 70 persen
Kepala Daerah Korup". tersedia di website www.tempo.co/read/news/2013/12/18, diakses tanggal 26 Desember 2013;

Poti, Jamhur. "Demokratisasi Media Massa dalam Prinsip Kebebasan". Jurnal Ilmu Politik dan Ilmu Pemerintahan. Vol. 1 No.1 Tahun 2011. Kepulauan Riau: Fakultas Ilmu Sosial dan Ilmu Politik UMRAH;

Pusat Studi Konstitusi FH Andalas. "Perkembangan Pengujian Perundang-Undangan di Mahkamah Konstitusi". Jurnal Konstitusi. Vol. 7 No. 6 Tahun 2010, Jakarta: Mahkamah Konstitusi;

Rahardjo, Satjipto. 2009. Negara Hukum yang Membahagiakan Rakyatnya. Yogyakarta: Genta Publishing;

Randang, Frankiano B. "Membangun Hukum Nasional yang Demokratis dan Cerdas Hukum". Jurnal Ilmiah Hukum Servanda. Vol. 3 No. 5 Januari 2009, Manado: FH UNSRAT;

Silaban, Fernandes Edy Syahputra. "Kebijakan Hukum Pidana Terhadap Pengaturan Tindak Pidana Narkotika Di Indonesia". Jurnal Mahupi, Vol. 1 No.1 Tahun 2013. Medan: Fakultas Hukum USU;

Yanti, Mery. "Menakar Perkembangan Demokrasi Di Aras Lokal". Jurnal Administratio. Vol. 3 No. 6 Tahun 2009, Lampung: Jurusan Administrasi Negara FISIP UNILA. 